\title{
Radiation protection in paediatrics age
}

\author{
Sergio Salerno*, Claudia Geraci \\ From 70th Congress of the Italian Society of Pediatrics, Joint National Meeting SIP, SICuPP, SITIP \\ Palermo, Italy. 11-14 June 2014
}

Radiological protection in paediatric population from medical imaging is a subject promoted by various international associations and it is becoming a main field of interest. Paediatric patients have a significant risk from ionizing radiation (IR) following $\mathrm{X}$-ray examination (chest, abdomen and skeletal segments), multidetector CT (MDCT) and PET imaging [1]. Their greater damage's risk is due to: growing tissues with elevated turnover and high radio sensitivity cellular, the high water content which amplifies the damage, the small body size that involves the exposure of large areas associated with the expectation of long- life makes possible the development of diseases resulting from genetic damage [1]. Also there is a huge increase of exposure due to imaging is recorded in many country also in Italy, in emergency and is mainly performed in "non paediatric hospitals" often with adult setting of the machine [2]. The first type of radioprotection is the use of alternatives imaging techniques; ETG and MR offer, in expert hands, a vital potential diagnostic in complete safety radio protectionist [3]. The radiologist who elects to perform the X-ray examination must be certain that this is justified and run with minimal doses for the same diagnostic benefit (As Low As Reasonably Achievable: ALARA). In these patients the X-ray studies is characterized by repeated examinations and this results in high doses even if only one exam does not deliver high levels of IR. MDCT examinations when strictly necessary, should be optimized "patient fit" in terms of scanning parameters $\mathrm{mAs}$ and $\mathrm{Kw}$ (according to age and weight of the patient the paediatric patient range from 700gr to $90 \mathrm{kgs})$, well collimation and only the region of interest should be examined and multiple sequence should be avoided [4]. Is a common idea that using paediatric protocols and alternative imaging techniques are important for reduce dose [4] and many authors suggested that the Size-Specific Dose Estimates (SSDE) received by the

\footnotetext{
Dipartimento di Biopatologia e Biotecnologie Mediche e Forensi, Università
} di Palermo, Italy

Submit your next manuscript to BioMed Central and take full advantage of:

- Convenient online submission

- Thorough peer review

- No space constraints or color figure charges

- Immediate publication on acceptance

- Inclusion in PubMed, CAS, Scopus and Google Scholar

- Research which is freely available for redistribution Submit your manuscript at
www.biomedcentral.com/submit C BioMed Central 